\title{
Plot Numbers Required to Determine Infiltration Rates and Sediment Production on Rangelands in South Central New Mexico
}

\author{
M. KARL WOOD
}

\section{Abstract}

Many studies have been made, and continue to be conducted, to determine infiltration rates and sediment production on rangelands. Most of these studies use small sample plots $\left(<2 \mathrm{~m}^{2}\right)$. This study determined the number of sample plots required to achieve confidence intervals of $\pm 10, \pm 20$ and $\pm 30 \%$ of the sample mean at 80,90 , and $95 \%$ probability levels. For 80 and $90 \%$ probability levels, $20 \%$ of the mean could be achieved with 1 to 5 plots for infiltration rates, and as low as 1 or as many as 263 plots for sediment production. For dry soil moisture conditions, infiltration rates could be estimated with 4 or 5 plots, with 10 to 12 plots needed for field capacity conditions to achieve $10 \%$ of the mean with $95 \%$ confidence. Achieving $10 \%$ of the mean with $95 \%$ confidence was not considered practical for sediment production.

\section{Key words: sampling methods, erosion hydrology}

Infiltration rate and sediment production studies have been conducted on many rangeland types in the United States (Blackburn et al. 1982); however, data on the impacts of most land management practices on infiltration and erosion are still lacking. Human demands on U.S. rangelands will increase as the human population increases and shifts to the western U.S. Watershed impact research should be intensified, and guidelines for data collection developed. In recent years, most research evaluating infiltration rates and sediment production on rangeland has been conducted with portable rainfall simulators on small plots $\left(1 \mathrm{~m}^{2}\right.$ or less). The number of plots or samples required to accurately and precisely estimate infiltration rates and sediment production has not been established for most range types. Studies that utilize an entire watershed as a sample plot often have only 1 sample per treatment (Hibbert et al. 1974, White et al. 1983, and Johnson et al. 1978). Studies that use sample plots of less than 1 hectare, but larger than 0.01 hectare, are usually limited to a few plots per treatment (Brown et al. 1983 and Gustafson et al. 1981). Studies that use small runoff plots $(<0.01 \mathrm{ha})$ usually use from 4 (Glover et al. 1983) to 12 plots (Wood and Blackburn 1981), or more per treatment. This study determined the number of plots required to evaluate infiltration rates and sediment production on native grassland range at Fort Stanton, New Mexico. The influence of collection time on results was also evaluated.

\section{Study Area}

The 2-year (1980-1981) study was conducted on a mesa top and a valley bottom on the Fort Stanton Experimental Range in Lincoln County in south-central New Mexico at latitude $33^{\circ} 30^{\prime}$ North and longitude $105^{\circ} 31^{\prime}$ West. The range is in foothills transition between shortgrass prairie and pinyon-juniper-oak woodland. Elevation of the 10,522-ha ranch varies from 1,890 to $2,286 \mathrm{~m}$, and topography consists of rolling hills and flat-topped mesas separated by deep canyons.

Mesa tops and bottomlands were dominated generally by herbaceous vegetation, whereas slopes and rocky ridges were dominated by woody species (Pieper et al. 1971). The major forage

Author is associate professor of range watershed management. New Mexico State University, Las Cruces 88003.

This is New Mexico Agricultural Experiment Station article series No. 1255

Manuscript accepted 3 November 1986 species was blue grama (Bouteloua gracilis [H.B.K.] Lag. ex Steud.), which was dominant or codominant on all sites. Other important grasses included wolftail (Lycurus phleoides H.B.K.), sand dropseed (Sporobolus cryptandrus [Torr.] Gray), mat muhly (Muhlenbergia richardsonis [Trin.] Rydb.), ring muhly (Muhlenbergia torreyi [Kunth] Hitchc.), red three awn (Aristida longiseta Rydb.), galleta (Hilaria jamesii[Torr.] Benth.), Hall's panic (Panicum hallii Vasey), and sideoats grama (Bouteloua curtipendula [Michx.] Torr.). Common forbs were Carruth sagewort (Artemisia carruthii Wood), scarlet globemallow (Sphaeralcea coccinea [Pursh] Rydb.), Dakota vervain (Verbena bipinnatifida Nutt.) and Rocky Mountain zinnia (Zinnia grandiflora Nutt.). Important woody species included pinyon pine ( Pinus edulis Engelm.), single-seeded juniper (Juniperus monosperma [Englem.] Sarg.), walking stick cholla (Opuntia imbricata [Haw.] DC.), and wavey-leaf oak (Quercus undulata Torr.). Also present were bottlebrush squirreltail (Sitanion hystrix [Nutt.] J. G. Smith) and broom snakeweed (Xanthocephalum sarothrae [Pursh] Skinners).

Mesa top study sites were located on the Dioxice series, which is a member of the fine-loamy, mixed, mesic family of Aridic Calciustolls. Soil depths were frequently $150 \mathrm{~cm}$ with good drainage. Valley bottom study sites were located at the bottom of major drainageways on the Manzano soil series, which are members of the fine-loamy, mixed, mesic family of Cumulic Haplustolls (USDA 1980). These soils are deep $(150 \mathrm{~cm})$ and well drained with surface textures varying from loam to silty clay loam.

Normal annual precipitation recorded at headquarters was 384 mm, of which $65 \%$ generally occurs from June through September. Summer precipitation is primarily from convection-type storms, that are often intense and localized.

Temperatures are mild with an annual mean of $11.1^{\circ} \mathrm{C}$. The range is from a mean minimum of $-.67^{\circ} \mathrm{C}$ in Janury to a mean maximum of $18.9^{\circ} \mathrm{C}$ in July. The average frost-free period is 161 days; the average date of last frost is $2 \mathrm{May}$, and the average date of the first frost is 10 October (Pieper et al. 1971).

\section{Methods}

Four grazed pastures and an area (7.5 ha) that had been excluded from livestock grazing since 1952 were selected as study sites on the mesa tops. Grazed pastures included 1 continuously grazed at a heavy stocking rate ( $510 \mathrm{ha}), 1$ continuously grazed at a moderate stocking rate ( $300 \mathrm{ha}$ ), and 2 pastures from a 4-pasture, 3-herd rotation system ( $400 \mathrm{ha}$ ) stocked at a heavy rate (17.35 ha/AU). Stocking rate of the moderate continuously grazed pasture (23.13 ha/ $\mathrm{AU}$ ) was about $25 \%$ lower than the heavy continuously and rotationally grazed pastures. In 1980, a rotation system was changed to the 4-pasture, 3-herd system grazing stocked at the heavy rate, except during summer (May through August) when the animals were concentrated in 1 pasture for breeding purposes. In this 4-pasture, 3-herd system, livestock were moved about every 3 months. The pastures were sampled immediately after 1 pasture had been rested for 3 months, and immediately after another pasture had been grazed for the full 9-month grazing period.

Treatments on the valley bottom were a grassland pasture study site ( $63 \mathrm{ha}$ ) moderately stocked in the summer at $2.5 \mathrm{ha} / \mathrm{AU}$, and a grassland pasture ( $55 \mathrm{ha}$ ) fertilized every other year since 1977 with 
$45 \mathrm{~kg} / \mathrm{ha}$ of urea and heavily stocked in the summer at $1.2 \mathrm{ha} / \mathrm{AU}$. Each pasture was divided into 3 areas to represent blocks. In each area, a mobile rainfall simulator (Blackburn et al. 1974) was used to simulate rainfall on 4 , randomly located $1-\mathrm{m}^{2}$ plots.

Simulated rainfall was applied at a rate of $7.5 \mathrm{~cm} / \mathrm{hr}$ for 45 minutes. This intensity of rainfall occurs every year or two for periods less than an hour. Average drop size was $2.5 \mathrm{~mm}$. Preliminary tests showed 45 minutes were required for the infiltration rate to become fairly constant when simulated rainfall was applied to plots at field capacity (Smith 1980). Runoff from plots was collected and pumped into plastic bottles where it was weighed at 5-minute intervals and converted to centimeters of runoff. Average infiltration rate was determined by subtracting runoff from measured precipitation at the given time intervals. This procedure does not account for losses from interception and evaporation, which were probably not significant. Plots were then covered with clear polyethylene plastic to prevent evaporation, ensuring fairly uniform soil moisture conditions for a second simulated rainfall application 24 hours later.

Runoff collected from each plot was thoroughly agitated and a 1 -liter subsample removed. Sediment was filtered off the subsample, dried at $100^{\circ} \mathrm{C}$ for 24 hours, weighed, and converted to sediment yield in kilograms per hectare.

The number of plots required for a given precision level in each grazing situation was calculated using the formula of Stein (1945):

$$
N=\frac{\left(\mathrm{t}^{2}\right)\left(\mathrm{s}^{2}\right)}{\mathrm{d}^{2}}
$$

In this formula, $N$ is the computed sample size, $t$ is the tabulated value for the desired confidence level and the degrees of freedom of the initial sample, $\mathrm{d}$ is the half-width of the desired confidence interval, and $s^{2}$ is the variance of the initial sample. The 80,90 , and 95\% probability levels were used to calculate sample sizes or the number of plots required to be within $\pm 10, \pm 20$, and $\pm 30 \%$ of the population mean.

\section{Results and Discussion}

At many probability levels and confidence intervals, 1 plot per treatment was adequate (Table 1). Calculations were rounded to the nearest whole number. Some calculated sample sizes were less than a half, but these were rounded to 1 because rounding to 0 would result in no plots being required. For infiltration rates, plot number requirements generally increased with a tighter confidence interval and higher probability level. A sample size of 12 plots was used to calculate the sample size requirements. For the $10 \%$ confidence interval, 12 plots were inadequate for the rotation treatments.

Sample size is directly proportional to the variance of the initial sample, as calculated in Stein's equation. Because of differences in antecedent soil moisture content, infiltration rates are often measured initially, then again after 24 hours (Blackburn et al. 1974, McGinty et al. 1979, Wood and Blackburn 1981). Treatment effects are compounded with large differences in soil moisture content. Generally, dry soils have higher infiltration rates than the same soils when wet. Data in the study were collected in June, 1 of the 3 driest months of the year. Soils were quite dry ( $<8 \% \mathrm{vol} / \mathrm{vol})$ and would be considered beyond the permanent wilting point for many irrigated crops. At dry moisture levels, variance among infiltration rates was less than when soils were near field capacity. Apparently, initial soil moisture differences are great only with frequent precipitation. Including infiltration rates for both dry and wet conditions would be meaningful and useful for runoff prediction and modeling. Plot numbers did not vary much between years, but large differences in plot requirement can be expected if precipitation varied greatly between years or measurements were made in different seasons.

More plots were required for wet soil moisture conditions than for dry conditions, within any 1 year on the valley bottoms (Table 3). Plot requirements between years were also similar. Under dry

Table 1. The number of sample plots required to achieve confidence intervals of $\pm 10, \pm 20, \pm 30 \%$ of the sample mean at $80,90,95 \%$ probability levels for infiltration rates in each and all treated areas on the mesa tops, Fort Stanton, New Mexico.

\begin{tabular}{|c|c|c|c|c|c|c|c|c|c|c|c|}
\hline \multirow[b]{2}{*}{ Year } & \multirow{2}{*}{ Treatment } & \multirow{2}{*}{$\begin{array}{l}\text { Soil } \\
\text { Condition }\end{array}$} & \multicolumn{3}{|c|}{$80 \%$} & \multicolumn{3}{|c|}{$90 \%$} & \multicolumn{3}{|c|}{$95 \%$} \\
\hline & & & \pm 30 & \pm 20 & \pm 10 & \pm 30 & \pm 20 & \pm 10 & \pm 30 & \pm 20 & \pm 10 \\
\hline \multirow[t]{10}{*}{1980} & $\mathrm{HC}^{1}$ & dry & 1 & 1 & 1 & 1 & 1 & 1 & 1 & 1 & 1 \\
\hline & & wet & $i$ & $i$ & 3 & 1 & 1 & 6 & 1 & 2 & 8 \\
\hline & MC & dry & 1 & 1 & 1 & 1 & $i$ & 2 & 1 & 1 & 3 \\
\hline & & wet & 1 & 1 & 5 & 1 & 2 & 8 & 1 & 3 & 12 \\
\hline & RG & dry & 1 & 1 & 2 & 1 & 1 & 4 & $i$ & 2 & 6 \\
\hline & & wet & 1 & 3 & 10 & 2 & 4 & 18 & 3 & 7 & 27 \\
\hline & $\mathrm{RR}$ & dry & 1 & 1 & 1 & 1 & 1 & 1 & 1 & I & 2 \\
\hline & & wet & 1 & 1 & 4 & 1 & 2 & 7 & i & 3 & 11 \\
\hline & EX & dry & 1 & 1 & 1 & 1 & 1 & 1 & 1 & 1 & 1 \\
\hline & & wet & 1 & 2 & 1 & 1 & 1 & 1 & i & i & 1 \\
\hline \multirow[t]{10}{*}{1981} & $\mathrm{HC}$ & dry & 1 & 1 & $i$ & 1 & 1 & 2 & 1 & 1 & 3 \\
\hline & & wet & 1 & 1 & 4 & 1 & 2 & 7 & 1 & 3 & 7 \\
\hline & MC & dry & 1 & $i$ & 1 & 1 & 1 & 1 & 1 & 1 & 1 \\
\hline & & wet & 1 & 1 & 2 & 1 & 1 & 3 & 1 & 1 & 5 \\
\hline & RG & dry & 1 & 1 & 2 & 1 & 1 & 3 & 1 & 1 & 4 \\
\hline & & wet & 1 & 1 & 3 & 1 & 1 & 6 & 1 & 2 & 9 \\
\hline & $\mathbf{R} \mathbf{R}$ & dry & 1 & 1 & 2 & 1 & 1 & 3 & 1 & 1 & 5 \\
\hline & & wet & 1 & 2 & 8 & 2 & 3 & 14 & 2 & 5 & 20 \\
\hline & EX & dry & 1 & 1 & 1 & $i$ & 1 & 1 & 1 & 1 & 1 \\
\hline & & wet & 1 & 1 & 1 & 1 & 1 & 1 & 1 & 1 & 1 \\
\hline Mean 1980 & & & 1 & 1 & 3 & 1 & 2 & 5 & 1 & 2 & 7 \\
\hline Mean 1981 & & & 1 & 1 & 2 & 1 & 1 & 4 & 1 & 2 & 6 \\
\hline Mean dry & & & 1 & $i$ & 1 & 1 & 1 & 2 & 1 & 1 & 3 \\
\hline Mean wet & & & 1 & 1 & 4 & 1 & 2 & 7 & 1 & 3 & 10 \\
\hline Total mean & & & 1 & 1 & 3 & 1 & 1 & 4 & 1 & 2 & 6 \\
\hline
\end{tabular}

'HC = heavily stocked, continuously grazed .

$\mathrm{MC}=$ moderately stocked, continuously grazed.

$\mathrm{RG}=$ rotation, after grazing period .

$R R=$ rotation, after rest period.

EX = exclusion from grazing. 
conditions, the unfertilized, or control treatment required $50 \%$ more plots than the fertilized treatment for dry conditions, while wet conditions gave nearly equal plot requirements. When the soil was dry, plant conditions had a great influence on infiltration rates, and the fertilized areas were most homogeneous. With wet conditions, the heterogeneity of the plant community was less important to infiltration rates. Sample plot numbers were about the same from year to year. Overall, a larger sample size was required for the valley bottoms than the mesa tops.

The sediment production data were significantly skewed; thus the data were transformed logarithmically. Sample sizes to ade- quately determine sediment production were of ten 10 times greater than for infiltration rates at the same confidence interval and probability level. The number of sample plots required at the \pm 20 and $\pm 10 \%$ confidence interval ranged from 1 to 396 , depending on the treatment. When the means were considered, these confidence intervals are probably unattainable with the time and funds associated with most research projects.

Under both dry and wet soil conditions, the fertilized treatment required $50 \%$ more plots than the unfertilized, or control treatment (Table 4). This is opposite of the comparisons for infiltration rates at this site. Apparently, the fertilized areas had more variability for

Table 2. The number of sample plots required to achieve confidence intervals of $\pm 10, \pm 10, \pm 30 \%$ of the same mean at 80,90 , and $95 \%$ probability levels for logarithmically transformed sediment production data in each and all treated areas on the mesa tops, Fort Stanton, New Mexico.

\begin{tabular}{|c|c|c|c|c|c|c|c|c|c|c|c|}
\hline \multirow[b]{2}{*}{ Year } & \multirow[b]{2}{*}{ Treatment } & \multirow{2}{*}{$\begin{array}{l}\text { Soil } \\
\text { Condition }\end{array}$} & \multicolumn{3}{|c|}{$80 \%$} & \multicolumn{3}{|c|}{$90 \%$} & \multicolumn{3}{|c|}{$95 \%$} \\
\hline & & & \pm 30 & \pm 20 & \pm 10 & \pm 30 & \pm 20 & \pm 10 & \pm 30 & \pm 20 & \pm 10 \\
\hline \multirow[t]{10}{*}{$\overline{1980}$} & $\mathrm{HC}^{1}$ & dry & 1 & 2 & 7 & 1 & 3 & 12 & 2 & 4 & 17 \\
\hline & & wet & 1 & 2 & 6 & 1 & 3 & 11 & 2 & 4 & 16 \\
\hline & $\mathrm{MC}$ & dry & 2 & 3 & 14 & 3 & 6 & 23 & 4 & 9 & 35 \\
\hline & & wet & 1 & 2 & 10 & 2 & 4 & 17 & 3 & 6 & 26 \\
\hline & RG & dry & i & 2 & 6 & 1 & 2 & 10 & 2 & 4 & 15 \\
\hline & & wet & 1 & 1 & 3 & 1 & 1 & 5 & 1 & 2 & 8 \\
\hline & $\mathbf{R} \mathbf{R}$ & dry & 1 & 2 & 7 & 1 & 3 & 11 & 2 & 4 & 17 \\
\hline & & wet & 1 & 1 & 5 & 1 & 2 & 8 & 1 & 3 & 12 \\
\hline & EX & dry & 17 & 38 & 152 & 29 & 66 & 263 & 44 & 99 & 396 \\
\hline & & wet & 11 & 25 & 98 & 19 & 43 & 170 & 28 & 64 & 256 \\
\hline \multirow[t]{10}{*}{1981} & $\mathrm{HC}$ & dry & 2 & 4 & 17 & 3 & 7 & 29 & 5 & 11 & 44 \\
\hline & & wet & 1 & 2 & 8 & 2 & 3 & 14 & 2 & 5 & 21 \\
\hline & MC & dry & 4 & 10 & 39 & 8 & 17 & 68 & 11 & 26 & 102 \\
\hline & & wet & 1 & 1 & 5 & 1 & 2 & 9 & 2 & 3 & 14 \\
\hline & RG & dry & 1 & 1 & 3 & 1 & 1 & 5 & 1 & 2 & 7 \\
\hline & & wet & 1 & 1 & 2 & 1 & 1 & 3 & 1 & 1 & 5 \\
\hline & $\mathbf{R} \mathbf{R}$ & dry & 1 & 1 & 4 & 1 & 2 & 7 & 1 & 3 & 10 \\
\hline & & wet & $i$ & 1 & 5 & 1 & 2 & 9 & 2 & 3 & 14 \\
\hline & EX & dry & 16 & 36 & 142 & 27 & 62 & 247 & 41 & 92 & 370 \\
\hline & & wet & 3 & 7 & 29 & 6 & 13 & 50 & 8 & 19 & 75 \\
\hline Mean 1980 & & & 4 & 8 & 31 & 6 & 13 & 53 & 9 & 20 & 80 \\
\hline Mean 1981 & & & 3 & 6 & 25 & 5 & 11 & 44 & 7 & 16 & 66 \\
\hline Mean dry & & & 5 & 9 & 39 & 8 & 17 & 68 & 11 & 25 & 101 \\
\hline Mean wet & & & 2 & 4 & 17 & 4 & 7 & 30 & 5 & 11 & 45 \\
\hline Total mean & & & 3 & 7 & 28 & 6 & 12 & 49 & 8 & 18 & 73 \\
\hline
\end{tabular}

'HC = heavily stocked, continuously grazed.

$M C=$ moderately stocked, continuously grazed.

$R G$ = rotation, after grazing period.

$\mathbf{R} \mathbf{R}=$ rotation, after rest period.

EX = exclusion from grazing.

Table 3. The number of sample plots required to achieve confidence intervals of $\pm 10, \pm 20, \pm 30 \%$ of the sample mean at 80,90 , and $95 \%$ probability levels for infiltration rates in each and all treated areas on the valley bottom study sites, Fort Stanton, New Mexico.

\begin{tabular}{|c|c|c|c|c|c|c|c|c|c|c|c|}
\hline \multirow[b]{2}{*}{ Year } & \multirow{2}{*}{\multicolumn{2}{|c|}{$\begin{array}{c}\text { Soil } \\
\text { Treatment Condition }\end{array}$}} & \multicolumn{3}{|c|}{$80 \%$} & \multicolumn{3}{|c|}{$90 \%$} & \multicolumn{3}{|c|}{$95 \%$} \\
\hline & & & \pm 30 & \pm 20 & \pm 10 & \pm 30 & \pm 20 & \pm 10 & \pm 30 & \pm 20 & \pm 10 \\
\hline 1980 & $\begin{array}{l}\text { Untreated } \\
\text { Fertilized }\end{array}$ & $\begin{array}{l}\text { dry } \\
\text { wet } \\
\text { dry } \\
\text { wet }\end{array}$ & $\begin{array}{l}1 \\
1 \\
1 \\
1\end{array}$ & $\begin{array}{l}1 \\
3 \\
1 \\
2\end{array}$ & $\begin{array}{r}4 \\
12 \\
3 \\
9\end{array}$ & $\begin{array}{l}1 \\
2 \\
1 \\
2\end{array}$ & $\begin{array}{l}1 \\
5 \\
1 \\
4\end{array}$ & $\begin{array}{r}8 \\
20 \\
5 \\
16\end{array}$ & $\begin{array}{l}1 \\
3 \\
1 \\
3\end{array}$ & $\begin{array}{l}3 \\
8 \\
2 \\
6\end{array}$ & $\begin{array}{r}12 \\
30 \\
8 \\
24\end{array}$ \\
\hline 1981 & $\begin{array}{l}\text { Untreated } \\
\text { Fertilized }\end{array}$ & $\begin{array}{l}\text { dry } \\
\text { wet } \\
\text { dry } \\
\text { wet }\end{array}$ & $\begin{array}{l}1 \\
1 \\
1 \\
1\end{array}$ & $\begin{array}{l}1 \\
2 \\
1 \\
1\end{array}$ & $\begin{array}{r}5 \\
10 \\
3 \\
5\end{array}$ & $\begin{array}{l}1 \\
2 \\
1 \\
1\end{array}$ & $\begin{array}{l}2 \\
4 \\
1 \\
2\end{array}$ & $\begin{array}{r}8 \\
17 \\
6 \\
9\end{array}$ & $\begin{array}{l}1 \\
3 \\
1 \\
2\end{array}$ & $\begin{array}{l}3 \\
6 \\
2 \\
3\end{array}$ & $\begin{array}{r}12 \\
25 \\
9 \\
14\end{array}$ \\
\hline 1982 & Untreated & wet & 1 & 1 & 4 & 1 & 2 & 6 & 1 & 2 & 9 \\
\hline 1981 & Fertilized & wet & 1 & 3 & 12 & 2 & 5 & 21 & 3 & 8 & 31 \\
\hline $\begin{array}{l}\text { Mean } 1980 \\
\text { Mean } 1981 \\
\text { Mean } 1982 \\
\text { Mean dry } \\
\text { Mean wet } \\
\text { Total mean }\end{array}$ & & & $\begin{array}{l}1 \\
1 \\
1 \\
1 \\
1 \\
1\end{array}$ & $\begin{array}{l}2 \\
1 \\
2 \\
1 \\
2 \\
2\end{array}$ & $\begin{array}{l}7 \\
6 \\
8 \\
4 \\
9 \\
7\end{array}$ & $\begin{array}{l}2 \\
1 \\
2 \\
1 \\
2 \\
1\end{array}$ & $\begin{array}{l}3 \\
2 \\
4 \\
2 \\
4 \\
3\end{array}$ & $\begin{array}{r}12 \\
10 \\
14 \\
7 \\
15 \\
12\end{array}$ & $\begin{array}{l}2 \\
2 \\
2 \\
2 \\
2 \\
2\end{array}$ & $\begin{array}{l}5 \\
4 \\
5 \\
2 \\
6 \\
4\end{array}$ & $\begin{array}{l}18 \\
15 \\
20 \\
10 \\
22 \\
17\end{array}$ \\
\hline
\end{tabular}


Table 4. The number of sample plots required to achieve confidence intervals of $\pm 10, \pm 20, \pm 30 \%$ of the sample mean at 80,90 , and $95 \%$ logarithmically transformed sediment production in each and all treated areas on the vally bottom study sites, Fort Stanton, New Mexico.

\begin{tabular}{|c|c|c|c|c|c|c|c|c|c|c|c|}
\hline \multirow[b]{2}{*}{ Year } & \multirow{2}{*}{ Treatment } & \multirow{2}{*}{$\begin{array}{l}\text { Soil } \\
\text { Condition }\end{array}$} & \multicolumn{3}{|c|}{$80 \%$} & \multicolumn{3}{|c|}{$90 \%$} & \multicolumn{3}{|c|}{$95 \%$} \\
\hline & & & \pm 30 & \pm 20 & \pm 10 & \pm 30 & \pm 20 & \pm 10 & \pm 30 & \pm 20 & \pm 10 \\
\hline 1980 & $\begin{array}{l}\text { Untreated } \\
\text { Fertilized }\end{array}$ & $\begin{array}{l}\text { dry } \\
\text { wet } \\
\text { dry } \\
\text { wet }\end{array}$ & $\begin{array}{l}1 \\
1 \\
1 \\
1\end{array}$ & $\begin{array}{l}2 \\
2 \\
1 \\
1\end{array}$ & $\begin{array}{l}9 \\
9 \\
3 \\
5\end{array}$ & $\begin{array}{l}2 \\
2 \\
1 \\
1\end{array}$ & $\begin{array}{l}4 \\
4 \\
1 \\
2\end{array}$ & $\begin{array}{r}15 \\
16 \\
5 \\
9\end{array}$ & $\begin{array}{l}3 \\
3 \\
1 \\
1\end{array}$ & $\begin{array}{l}6 \\
6 \\
2 \\
3\end{array}$ & $\begin{array}{r}22 \\
24 \\
7 \\
13\end{array}$ \\
\hline 1981 & $\begin{array}{l}\text { Untreated } \\
\text { Fertilized }\end{array}$ & $\begin{array}{l}\text { dry } \\
\text { wet } \\
\text { dry } \\
\text { wet }\end{array}$ & $\begin{array}{l}1 \\
1 \\
2 \\
1\end{array}$ & $\begin{array}{l}2 \\
1 \\
4 \\
3\end{array}$ & $\begin{array}{r}2 \\
2 \\
14 \\
12\end{array}$ & $\begin{array}{l}1 \\
1 \\
3 \\
2\end{array}$ & $\begin{array}{l}1 \\
1 \\
6 \\
5\end{array}$ & $\begin{array}{r}3 \\
3 \\
25 \\
21\end{array}$ & $\begin{array}{l}1 \\
1 \\
4 \\
4\end{array}$ & $\begin{array}{l}1 \\
1 \\
9 \\
8\end{array}$ & $\begin{array}{r}4 \\
4 \\
37 \\
32\end{array}$ \\
\hline 1982 & Untreated & wet & 1 & 1 & 1 & 1 & 1 & 1 & 1 & 1 & 1 \\
\hline 1981 & Fertilized & wet & 1 & 1 & 3 & 1 & 1 & 5 & 1 & 2 & 8 \\
\hline $\begin{array}{l}\text { Mean } 1980 \\
\text { Mean } 1981 \\
\text { Mean } 1982 \\
\text { Mean dry } \\
\text { Mean wet } \\
\text { Total mean }\end{array}$ & & & $\begin{array}{l}1 \\
1 \\
1 \\
1 \\
1 \\
1\end{array}$ & $\begin{array}{l}2 \\
2 \\
1 \\
2 \\
2 \\
2\end{array}$ & $\begin{array}{l}6 \\
8 \\
2 \\
7 \\
5 \\
6\end{array}$ & $\begin{array}{l}2 \\
2 \\
1 \\
2 \\
1 \\
2\end{array}$ & $\begin{array}{l}3 \\
3 \\
1 \\
3 \\
2 \\
3\end{array}$ & $\begin{array}{r}11 \\
13 \\
3 \\
12 \\
9 \\
10\end{array}$ & $\begin{array}{l}2 \\
2 \\
1 \\
2 \\
2 \\
2\end{array}$ & $\begin{array}{l}4 \\
5 \\
2 \\
4 \\
4 \\
4\end{array}$ & $\begin{array}{r}16 \\
19 \\
4 \\
18 \\
14 \\
15\end{array}$ \\
\hline
\end{tabular}

levels of loose soil particles or less stable aggregates on the surface. Fertilizing may be creating conditions similar to the exclosures on the mesa tops which required more sediment production plots than the adjacent grazed pasture.

Table 5 summarizes some of the data in Tables $1,2,3$, and 4 . The $\pm 10 \%$ confidence interval at $95 \%$ probability was chosen for discussion because this level shows the greatest differences between plot requirements. Table 5 can be used to relate stocking levels and graze and rest periods to sample plot requirements. On the mesa tops, a larger sample size was required when sites were rested and grazed in a grazing system than when they were continuously grazed at either stocking rate or continuously rested. This relationship was not apparent on the valley bottoms where the additional vegetal growth resulting from fertilization reduced plot-to-plot variation, at least under dry soil conditions. More plots were required for infiltration rates under wet conditions than for dry conditions.

On the mesa tops, fewer plots were required to measure sediment production when sites were in a grazing system with rest and graze periods than when they were continuously grazed at either stocking rate or continuously rested. The greatest sample size was required for the exclosure. Fewer plots were required for wet conditions than dry. The exclosure contained mature, full-statured bunchgrasses with small bare areas not covered by plant canopies. Bal- liette et al. (1986) measured sediment production for an entire runoff event plus sediment concentration on sagebrush-dominated rangeland in northern New Mexico. They found total sediment production to be less under sagebrush canopies than from the interspaces between shrubs. But sediment concentration was greater from the canopy-covered zones. They attributed this greater concentration to a loose, friable soil surface that was protected from the compacting forces of rain and trampling. These sagebrush canopy and interspace zones are similar to the bunchgrass canopy and interspace zones found in this study but on a much larger scale. The bunchgrass community cannot be easily stratified because of the small plot sizes that would be required. Wilcox (1985) measured sediment concentration at 5-minute intervals for runoff from a 45-minute storm in the Guadalupe Mountains in southeastern New Mexico. Sediment concentration was greater and more variable at the beginning of the runoff hydrograph and diminished throughout the event. These 2 studies may help explain that protected surface soils are loose, friable, and erratic, which would lead to greater sediment production variability in the exclosure. This would result in a high sample plot requirement. It would also help explain why more variance was found for dry soil conditions than for wet.

Data from this study suggest 4 or 5 sample plots are adequate for estimating infiltration rates for relatively dry soil moisture condi-

Table 5. The number of sample plots required to achieve $\pm 10 \%$ confidence interval of the sample mean at the $95 \%$ probability level for infiltration rates and sediment production for all treatments and years on the mesa top and valley bottom study sites, Fort Stanton, New Mexico.

\begin{tabular}{|c|c|c|c|c|c|c|}
\hline \multirow[t]{2}{*}{ Location } & \multirow[t]{2}{*}{ Treatment } & \multirow[t]{2}{*}{ Stocking level } & \multicolumn{2}{|c|}{$\begin{array}{c}\text { Infiltration rate plots required } \\
\pm 10 \% \text { at } 95 \%\end{array}$} & \multicolumn{2}{|c|}{$\begin{array}{l}\text { Sediment production plots required } \\
\pm 10 \% \text { at } 95 \%\end{array}$} \\
\hline & & & Dry & Wet & Dry & Wet \\
\hline Mesa Top & $\begin{array}{l}\text { HC } \\
\text { RG } \\
\text { RR } \\
\text { MC } \\
\text { EX }\end{array}$ & $\begin{array}{l}17 \mathrm{ha} / \mathrm{AU} / \mathrm{yr} \\
17 \mathrm{ha} / \mathrm{AU} / \mathrm{yr} \\
17 \mathrm{ha} / \mathrm{AU} / \mathrm{yr} \\
23 \mathrm{ha} / \mathrm{AU} / \mathrm{yr}\end{array}$ & $\begin{array}{l}2 \\
5 \\
4 \\
2 \\
1\end{array}$ & $\begin{array}{r}8 \\
18 \\
16 \\
8 \\
1\end{array}$ & $\begin{array}{r}30 \\
11 \\
14 \\
68 \\
383\end{array}$ & $\begin{array}{r}18 \\
6 \\
13 \\
20 \\
166\end{array}$ \\
\hline \multirow[t]{2}{*}{ Valley Bottom } & Untreated & $2.5 \mathrm{ha} / \mathrm{AU} / 3 \mathrm{mo}$ & 12 & 21 & 13 & 10 \\
\hline & Fertilized & $1.2 \mathrm{ha} / \mathrm{AU} / 3 \mathrm{mo}$ & 8 & 23 & 22 & 18 \\
\hline
\end{tabular}

'HC = heavily stocked, continuously grazed .

MC = moderately stocked, continuously grazed.

RG = rotation, after grazing period

$\mathbf{R R}=$ rotation, after rest period.

$\mathrm{EX}=$ exclusion from grazing. 
tions if a level of $95 \%$ confidence within $10 \%$ of the mean is desirable. Ten or 12 plots are probably needed for field capacity conditions at the same level. At least a dozen plots would be needed for sediment production. Attempting to be within $10 \%$ of the mean at a $95 \%$ confidence level is a worthy goal for laboratory and greenhouse studies where the potting medium and climates are carefully controlled. For heterogeneous range conditions, an 80 or $90 \%$ probability level and a confidence interval of 20 to $30 \%$ of the mean are much more realistic and affordable. On these range sites, these probability levels and confidence intervals could be achieved with only 4 or 5 sample plots in most situations.

\section{Literature Cited}

Balliette, J.F., K.C. McDaniel, and M.K. Wood. 1986. Infiltration and sediment production following chemical control of sagebrush in New Mexico. J. Range Manage. 39:160-165.

Blackburn, W.H., R.O. Meeuwig, and C.M. Skau. 1974. A mobile infiltrometer for use on rangeland. J. Range Manage. 27:322-323.

Blackburn, W.H., R.W. Knight, and M.K. Wood. 1982. Impacts of grazing on watersheds. Texas Agr. Exp. Sta. Rep. MP1496.

Brown, J.C., R.A. Evans, and J.A. Young. 1983. Effects of certain range improvement practices on infiltration rates and soil erosion at the Gund Ranch Nevada. Abst. Annual Mtg. Soc. Range Manage.

Glover, C.R., M.K. Wood, J.M. Fowler, and G.V. Sabol. 1983. Assessment of best management practices for non-point pollution control. New Mexico State Univ. Coop. Extension Cir. 499.

Gustafson, P.L., P.D. Green, and R.C. Hooper. 1981. Rainfall simulation to determine grazing management effects on upland hydrology. Abst. Annual Mtg. Soc. Range Manage.
Hibbert, A.R., E.A. Davis, and D.G. Scholl. 1974. Chaparral conversion potential in Arizona. USDA Forest Serv. Res. Paper RM-126.

Johnson, S.R., H.L. Gary, S.L. Ponce. 1978. Range cattle impacts on stream water quality in the Colorado front ranges. USDA Forest Serv. Res. Note RM-359.

McGinty, W.A., F.E. Smeins, and L.B. Merrill. 1979. Influence of soil, vegetation, and grazing management on infiltration rate and sediment production of Edwards Plateau rangeland. J. Range Manage. 32:33-37.

Pieper, R.D., J.R. Montoyk, and V.L. Groce. 1971. Site characteristics on pinyon-juniper and blue grama ranges in south-central New Mexico. New Mexico Agr. Exp. Sta. Bull. 573.

Smith, R.P. 1980. The influence of different grazing practices on infiltration rates and sediment production at Fort Stanton, New Mexico. M.S. Thesis, New Mexico State Univ., Las Cruces.

Stein, C. 1945. A 2-sample test for a linear hypothesis whose power is independent of the variance. Ann. Math. Stat. 16:243-248.

USDA. 1980. Range site description. USDA Agr., Soil Conserv. Serv. NM MLRA G70-109-N.

White, R.K., R.W. Van Keuren, L.B. Owens, W.M. Edwards, and R.H. Miller. 1983. Effects of livestock pasturing on nonpoint surface runoff. U.S. Environ. Protection Agency. EPA-600/S2-83-011.

Wilcox, B.P. 1985. Infiltration and erosion investigations in the Guadalupe Mountains of New Mexico. Ph.D. Diss., New Mexico State Univ., Las Cruces.

Wood, M.K. and W.H. Blackburn. 1981. Grazing systems: their influence on infiltration rates in the Rollings Plains of Texas. J. Range Manage. 34:331-335.

\title{
RANGELAND HYDROLOGY
}

\author{
by Farrel A. Branson, Gerald F. Gifford, Kenneth G. Renard, and \\ Richard F. Hadley
}

Unique in its emphasis on the hydrology of rangelands. primarily arid and semiarid lands. RANGELAND HYDROLOGY provides a text for one aspect of range management where none has existed before. This expanded Second Edition presents in-depth information for those who must manage rangeland or respond to questions about the impacts of land use practices on hydrology.

Included in the new Second Edition are a chapter on modeling with approaches to predicting the effects of land use, and a chapter on the rapidly developing field of snow pack management.

The 352-pages include 197 illustrations, providing rapid access to an assembly of data found nowhere else and useful in the preparation of environmental impact statements. Extensive bibliographic material with each chapter and a subject matter index add to the useableness of the book.

Range scientists and managers, soil conservationists, hydrologists, agricultural engineers, land reclamation specialists, wildlife managers, graduate and undergraduate students and their professors, as well as all interested in the hydrology of arid lands will find RANGELAND HYDROLOGY a valuable addition to their libraries. (352 pages paper laminated cover $\$ 15.00$ US) 